\title{
Fostering Local Economic Development through Community Informatics: A Soft Systems Approach Case Study.
}

\author{
Faustin Kamuzora
}

\begin{abstract}
Information is lifeblood of tourism business, thus, effective efforts to empower members of rural communities to benefit sustainably from tourism industry should involve information management, inter alia. The paper details a case study conducted in Lushoto District, Tanzania where members of Friends of Usambara group participated in a process of empowering by uplifting their information management skills. The skills included information system analysis and development, computing as well as web developing.

The case study employed a Community Informatics approach which is the application of information and communications technologies (ICTs) to enable community processes such as local economic development. Since such processes are complex and adaptive, the paper demonstrates application of one of Soft Operation Research (SOR) methods, namely, Soft System Methodology (SSM) in trying to empower members of community solve their economic challenges. Using some of SSM tools, participants in the case study were able to structure problem situation, create rich pictures, name relevant systems, define human activity systems, create stakeholders diagrams, analyse information and redesign information collection tools, and learn web authoring. These activities empowered the participants to undertake rural tourism business more effectively.
\end{abstract}

Key words: Information, Usambara, Tanzania, community, technology

\section{Introduction}

Despite the fact that tourism is considered as a largest industry in the world economy, its contribution in rural development endeavours is usually undermined by leakage effects. However, when members of communities were tourist attractions are located participate actively in tourism value chain, economic benefits are likely to benefit local economic development. Since tourism is basically information business, for rural communities to participate fully and actively in tourism value chain, capacity to manage information throughout customer / tourist journey (from pre-travel and post destination visit) needs to be strengthened. There is ample evidence that the strengthening can be done through community informatics process.

According to (Gurstein, 2001), "Community Informatics (CI) is the application of information and communications technologies (ICTs) to enable community processes and the achievement of community objectives... and particularly to support local economic development, social justice, and political empowerment using the Internet". In this case study, CI was employed to empower a community in Lushoto district, Tanzania through improving rural tourism information system. The community is known as Friends of Usambara Society (FoUS) which was formed in 1996 following a Dutch Aid Agency (SNV) effort of funding the Tanzania Cultural Tourism Programme (CTP). The overall goals of the society are to develop and promote sustainable tourism in the Usambara Mountains in Tanga region and to contribute to the conservation of the area's cultural and natural resources through sustainable tourism. To achieve this, the society 
charges a fee to tourists who receive tour guiding services by members of the society. The charged fees are distributed to three main components, namely, allowance for tour guide(s), society's portion, and village development fund (VDF). The VDF is supposed to be used to fund some projects in villages where tourist attractions are located. Given a nature fuzziness of undertaking such an endeavour dealing with rural development, soft operation research (SOR) tools were considered more appropriate to synthesise some of the society's processes. One of the major tools employed was Checkland's soft system methodology. The following section briefly discusses efficacy of SOR.

\section{Soft Systems Approach (SSM) as a Tool of Soft Operation Research}

Operation research (OR) traditionally developed from science, mathematics and statistics, and most of its early methods and techniques were of that kind. However, it has long been clear that many real problems in societies such as those involving socioeconomic development of poor communities and economy in general, are complex and messy, thus are simply not amenable purely to mathematical modeling. In response to this, a range of methods that are rigorous but more qualitative in nature continue to be developed for helping to structure these complex problems (Various, 2009). Some of these methods form soft operation research (SOR). The SOR methods, therefore, usually involve the active participation of clients in exploring problem structures and searching for desirable outcomes. Well-established examples are: Soft Systems Methodology, Viable Systems Model, Total Systems Intervention, Decision Trees and Influence Diagrams, Cognitive Mapping, Strategic Choice Approach, Strategic Assumption Surfacing and Testing Scenario Planning, Interactive Planning, Robustness Analysis, Meta- and Hypergames Repertory Grid Technique, Delphi Methods, Political Economic Sociocultural and Technological, and Strengths Weaknesses Opportunities and Threats Analyses, and Multimethodology. In other words, the soft in soft OR simply refers to the orientation of the approach as qualitative or interpretative rather than quantitative, as is the focus of hard OR. The distinction between hard and soft OR is perhaps best highlighted by the underlying assumptions of each school of thinking as depicted Table 1. 
Table 1: The Assumptions Made by Hard and Soft Operational Research

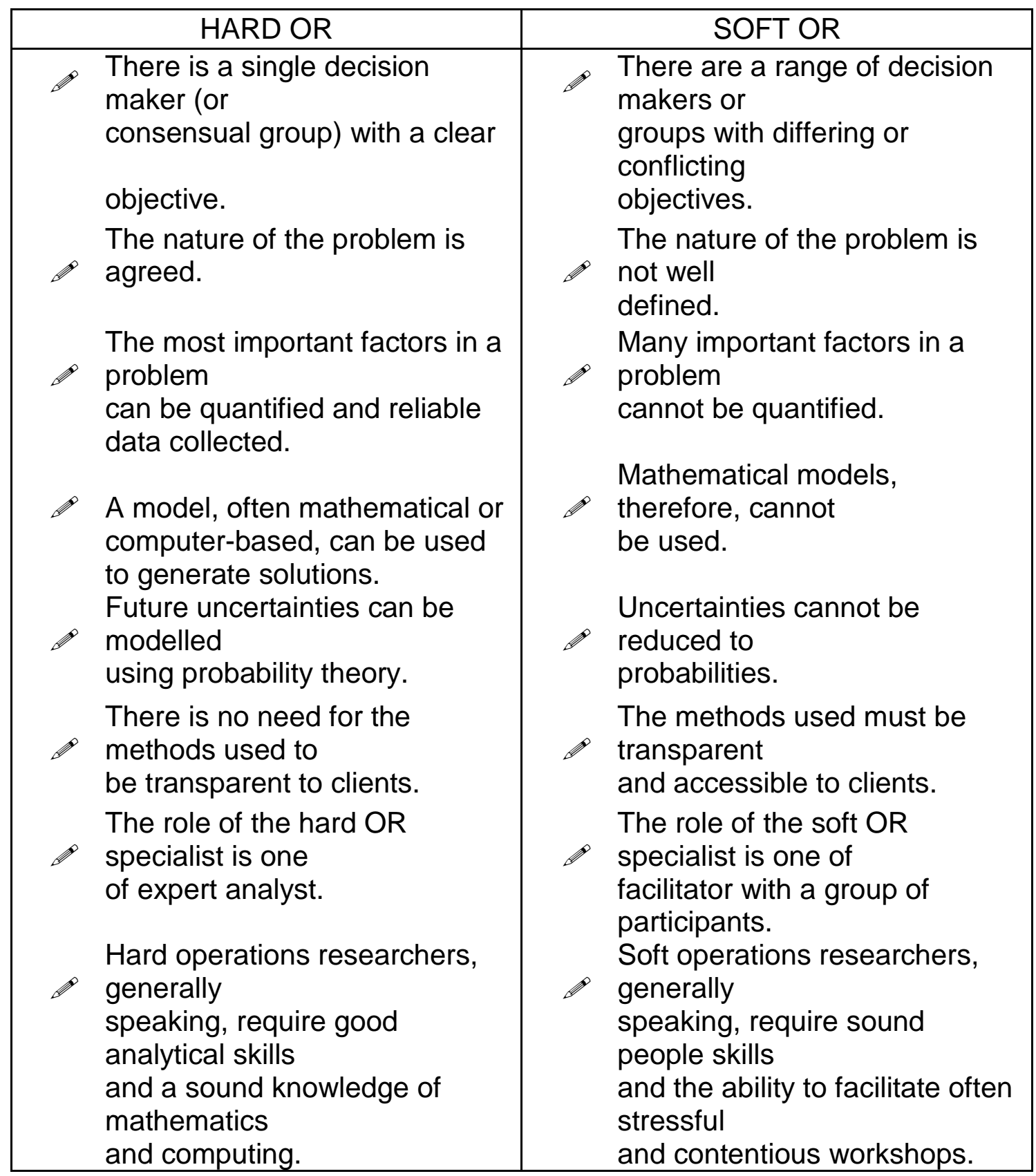

Source: (Heyer, 2004)

In this case study SSM was selected due to its versatility of its tools. For example, SSM tools that were employed in conducting the action research (AR) included the Rich Pictures (P.B. Checkland \& Holwell, 1998). The aim of employing the Rich Pictures was that participants would be empowered to appreciate the importance of effective participation in rural tourism value chain for improving experiences of the visitors in the destination. Similarly, the participants would participate in designing improved rural tourism strategies in their area, particularly tourism information systems management. The SSM is appropriate in the 
understanding of tourism because SSM compares the world (society) as it is to how it could be under different circumstances (Carlsen, 1999). Specifically, "Rich Pictures in SSM aim at understanding human activity systems in a way that is meaningful to the actors in that system" (Monk \& Howard, 1998):22.

In addition, the success of SSM has been its flexibility and adaptability in application in various circumstances. In this study SSM version 3 was employed as it was considered the most suitable for the situation in Lushoto district. The version had five stages as delineated by Checkland and Holwell (P.B. Checkland \& Holwell, 1998) as depicted in Figure 1.

Figure 1: Soft system methodology version 3 stages

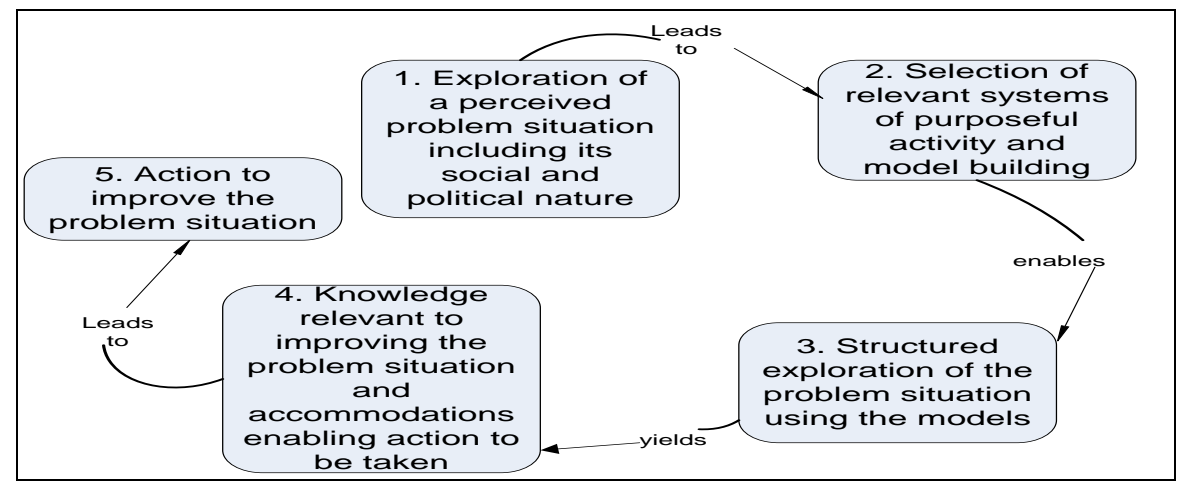

Source: (P.B. Checkland \& Holwell, 1998)

Step one is the exploration of a perceived problem situation including its social and political nature. This step leads to step two which is the selection of relevant systems of purposeful activity and model building. On the other hand, step 3 is an exploration of structured problem situation using models which yields to step four. Step four is gaining relevant knowledge to improving the problem situation and accommodations enabling action to be taken. Completion of step four leads to taking action to improve the situation as step five. However, these steps appear to end with taking action without giving room for evaluation of the action and incorporate lessons learned in a new process. Thus, a participatory action research (PAR) was deemed most pragmatic research design to employ in order to get an opportunity of conducting an evaluation of measures of improving the community information system.

\section{Community Informatics and Participatory Action Research Design}

As stated earlier, community informatics practice seeks to expand the digital divide conversation beyond infrastructure and into the realm of community practitioners. The conversation include developing strategies and applications for using ICT to support local economic development, social justice and political empowerment; ensuring local access to education and health services; enabling local control of information production and distribution; and, ensuring the survival and continuing vitality of indigenous cultures are among the most significant possible applications and goals (Gurstein, 2001) - p. 46-47 
In addition, PAR is a cognitive process that depends on the social interaction between the observers and stakeholders in their surroundings and it can advance our understanding of a phenomenon (Baskerville \& Wood-Harper, 1998). In this case the phenomenon under study was the knowledge of various actors in rural tourism on their roles and responsibilities to deliver quality services, particularly tourist information management, for the visiting tourists. Also, PAR assists in practical problem solving and expands scientific knowledge, as well as enhances the competencies of the respective actors (Hult \& Lennung, 1980).

As stated above, the case study used the SSM for solving the problems in information management that the society was facing. The problem situation involved the Friends of Usambara Society (FoUS). The problem was noted by the author through participatory observation methods during the initial phase of the research. The aim of the study was to investigate and improve the rural/community tourism information system (TIS). Improving TIS aimed to increase efficiency and effectiveness of community tourism activities. For example, the FoUS members were trained in web design using Nvu web authoring tool. Nvu is open source software with enhanced graphical user interface (GUI) similar to proprietary web tools such as Macromedia Dreamweaver or Microsoft FrontPage. However, at a later stage the members suggested that it would be proper to involve the top leadership of the district so that tourism promotion could be part of the district electronic governance endeavour.

In addition, participatory discussions were conducted to demonstrate connectedness and interdependence of various stakeholders in rural tourism value chain from both supply and demand sides. On the supply side several local stakeholders' roles were delineated by participants by drawing stakeholders' diagrams. On the demand side, the respondents (international tourists) identified several areas and activities which would assist the communities to improve and provide better tourist services. In order to integrate both sides of the value chain (supply and demand), the participants drew the Rich Pictures of their tourist products based on soft systems methodology (SSM) and the action research method. These visual tools (stakeholders' diagrams and Rich Pictures) helped the participants in better understanding their roles and appreciate the connectivity of other individuals and institutions in the tourism system and the role played by effective information system. Below is a brief description of the results of participatory action research and SSM as were used in tourism information systems development (ISD) in the case study.

\section{Soft Systems Methodology (SSM) Results of Friends of Usambara Society Case Study}

Several authors have detailed the use of case studies in social research, (see for example (Guba \& Lincoln, 1994)). Case studies are used to describe relationships which exist in reality, usually within a single organisation. The strength of case studies includes the ability to capture the local situation in detail and with respect to more variables than is possible with surveys. The following is an account of some of the results from the case study.

\section{SSM Training Seminar Output}

A preliminary research had been conducted by the author earlier and selected Lushoto as the case study. Lushoto was one of the selected areas because it was classified as one of the most successful modules under CTP (Mwenguo, 2003). The following is a brief discussion on how the above seminar was conducted to a selected focus group of participants from FoUS as well from 
the District Council. The group included 12 participants, whereby ten were members of FoUS and the remaining two were from the council (commonly known as District Executive Director (DED) office).

\section{Results from Focus Group Discussion}

A discussion was carried out in both languages (English as well as Kiswahili) as was convenient to participants. The author had prepared a handout which members were asked to read later on after the discussion. Participants were informed that information is lifeblood of the tourism industry. In the discussion on the source of information for tourists visiting Lushoto, the tour guides estimated that the Guide books were the major source. They listed Rough Guide as a major source of information followed by Lonely Planet, and Africa View as the third source. Other sources of information were said to be a word of mouth and the Internet. However, the interlocutors' experiences could not estimate percentage contribution of the above sources. Given that there was no data to support or refute the above claim, the author was asked to conduct the actual survey ${ }^{1}$ to determine the extent each source contributed as a pre-travel source of Lushoto tourist information. Since channels of sources of tourism information are usually interdependent, results from the survey would assist the Society on how to distribute their promotion efforts.

Participants discussed a need of updating the information on their tourist products. At the time of research, most of the promotion channels used by FoUS were not updated. Since a frequency of publication and content of international guidebooks was out control of FoUS, it was revealed that at times the Lushoto destination had suffered from bad reporting. This kind of vulnerability emanated from the fact that the content of these guidebooks was solely a responsibility of companies producing them. Participants were informed of the power of the web, whereby by owning a website and by having requisite skills, one could update at will and determine type of content to include on the site. The discussion which ensued dealt mainly on the empowering aspects and possibly reducing print costs of paper based promotion materials such as brochures and guide books. It was also revealed that the above problem of not updating both brochures and Usambara View Guide was caused by the financial inadequacy which was facing the society.

After the first day of rapport building, the training for the actual SSM workshop began on the following day.

\section{Introduction to SSM Training Workshop}

Participants were introduced to the SSM due to one of its strengths of acknowledging that fuzzy problems can be best analysed in a systems way. The author presented a pictorial diagram of the tourism system and required members to locate where the society belonged. There was a discussion as to whether they fell under public local destination management organisation, attractions or transit and inbound tour operator. What was clear from the discussion was that the participants were not sure where they belonged from the presented tourism system diagram that was adopted from Buhalis (Buhalis, 2003, p. 82). In addition, the author asked the participants to evaluate their relationship with the district council authorities. Even though there seemed a consensus that the relationship was warm but not collaborative since the council did not consider

\footnotetext{
${ }^{1}$ A survey was conducted. However, results from the survey do not form part of this paper.
} 
tourism in its activities. The researcher could sense that the participants were not disclosing everything. The facial expression (body language) of many participants was not supporting the verbal message that was being delivered. The researcher came to learn later that there was a simmering conflict with some of the villages on the allocation of funds from tourism. A particular case that was cited was Irente village that had been dismayed by little fund that was coming in the village development fund (VDF) despite a surge in a number of tourists. The village was threatening to erect a gate on the Irente Viewpoint, the most famous tourist attraction in Lushoto, so as to collect entry fee.

\section{Construction of Rich Pictures}

After the above introduction to SSM, two groups were formed and started to work on Rich Pictures and the Naming of the Relevant Systems using the CATWOE tool (P.B. Checkland \& Holwell, 1998). The tool helps in analyzing the Root Definition as per each letter of the acronym, where $\mathrm{C}$ stands for Customer, A for Actors, $\mathrm{T}$ for Transformation, $\mathrm{W}$ for Weltanschauung (German for world view), O for Owner and, E for Environmental constraints. Specifically, Box 1 briefly provides a definition of each term in SSM context.

\section{Box 1: Customer, Actor, Transformation, Weltanchauung, Owner and Environment}

Customer: everyone who stands to gain benefits from a system is considered as a customer of the system. If the system involves sacrifices such as lay offs, then those victims must also be counted as customers (beneficiaries or the victims of $\mathrm{T}$ ).

Actor: The actors perform the activities defined in the system (those who would do T).

Transformation process: This is shown as the conversion of input to output.

Weltanschauung: The German expression for world view. This world view makes the transformation process meaningful in context.

Owner: Every system has some proprietor, who has the power to start up and shut down the system.

Environmental constraints: External elements exist outside the system which it takes as given. These constraints include organizational policies as well as legal and ethical matters (environment elements outside the system which it takes as a given).

\section{(CATWOE)}

Source: Adapted from Checkland (P.B. Checkland, 1990, p. 35)

\section{Identified Problems and Challenges \\ i. $\quad$ Lack of updating the promotion materials}

As stated earlier, the group members claimed that most of the information on the society has not been updated. For example, the Usambara View Guide had been out of print for three years. Some information in last edition was no longer valid. An example of this was the telephone number which was out of service and a mobile phone service which had been in Lushoto over two years yet this information was not reflected in the Guide as well as in the brochure. However, there was a complaint that even though it was expensive to update the information on tourism in Lushoto, there was a problem of free riders. Those companies that were not investing in promoting tourism in Lushoto did benefit from an increased level of tourists arrivals without expending their resources. The researcher informed the participants that to a certain extent the free rider's problem was hard to prevent but in some cases tourist stakeholders had to decide to cooperate and compete (co-option) simultaneously. The members of FoUS were encouraged to 
look into this possibility of cooperating and simultaneously competing with two other firms that were formed by individuals in order to compete with FoUS.

\section{ii. $\quad$ Lack of new tourist products}

Members asserted that the tourism products that had been promoted in Lushoto had been static. There have been no efforts to create new products. This was attributed to a free rider problem as well as lack of creativity. Due to lack of new products there was no incentive for repeated visitors to revisit Lushoto. This explanation tallied very well with Butler's tourism lifecycle model (Butler, 1980) which is summarized by Russell and Faulkner (Russell \& Faulkner, 2004, p. 562) as follows " ... the evolution of destinations follows an S-shaped curve and experiences a series of stages from exploration to involvement, development, consolidation, stagnation and either decline or rejuvenation." Hence the participants' fear that lack of innovation to come up with new tourism products in Lushoto may result in a decline in demand of the products which had been offered from 1996. A lack of new products reduces the chance of repeat visitors who are considered to be vital in terms of marketing products by word of mouth. In order for destination to develop on a sustainable basis, the role of innovation has been acknowledged by several scholars such as Stamboulis and Skayannis (Stamboulis \& Skayannis, 2003).

\section{iii. $\quad$ Few visible information/signs to guide visitors}

The group claimed that promotion of tourism activities could be enhanced if more visible signs were erected along the Dar es Salaam-Arusha highway, particularly at Mombo where the highway branches to Lushoto.

\section{iv. Lack of collecting enough information from visitors/tourists}

The group asserted that there has been a reduced drive to collect data from the visitors. In past more data was collected from the visitors through a survey in which more detailed information was obtained. An example of the information that was collected through a survey included how much money a tourist was planning to spend or had spent in Lushoto, duration of stay, last destination before arriving in Lushoto, country of origin, age group, and visitor's sex, inter alia. At the time of research, the office did not have correct information on the number of arrivals let alone where they come from and other important variables pertaining to visitors.

The author informed the participants on the importance of collecting relevant data from visitors where it possible. The information from visitors could be used to better the services provided as well as for the customer relationship management (CRM). However, CRM is possible to be implemented at a low cost if one collects an e-mail address of the visitor; otherwise, it is expensive to communicate with a customer through other means when the visitor has returned to his/her country. Furthermore, the author informed the participants that from his experience most of the guest books in Tanzania were still printed with the same column headings (field headings) as if there has been no change in the way people communicated. In other words, the innovation of adding a column for e-mail address or mobile phone number had not been taken up by the designers of the guest books in the country.

\section{v. Information Management Problem}

It was discussed that despite the low drive of data collection, the data that has been collected has not been manipulated enough to yield more information that can be useful to the society. Close 
observation in the office showed that up to 2001 some information had been analysed and presented in charts, but no other information had been displayed after this period. It was later revealed that this was done by the help of SNV before the Cultural Tourism Programme project ended in 2002. In the course of discussion, it was agreed that in order to manipulate data one needs the requisite skills. There was a skill gap that needed to be filled through appropriate training. Another requirement for easy data manipulation is the technology, namely, appropriate software and hardware.

\section{vi. Questioned Legitimacy}

As described earlier, due to lack of proper communication to some villages (for example Irente village), legitimacy of FoUS was being questioned by some villagers. It was resolved that the communication be strengthened to solve this pending impasse.

\section{Structuring Problem Situation as per SSM}

The above problems, as identified by the participants, could be termed unstructured as per SSM parlance. After the two groups had presented their thoughts on the problem, the author took them through the stage of analyzing the problem in more formalized manner as presented below. Three kind of analyses were conducted, namely, intervention analysis, social and cultural analysis and power analysis.

\section{Analysis One: Intervention Analysis}

The participants were requested to try to analyse the possible intervention by using roles of actors in the above identified problems. The actors were clients, problem solver, available resources, and problem owner. The exercise was not relatively easy for the participants and it took longer to complete after several consultations with the author in plenary sessions. The output of the discussion is summarised in Box 2.

Box 2: Intervention Analysis: Role of Actors

Client: FoUS

Client's aspirations: To improve the skills to manage tourist information

Problem solvers: FoUS members and Mzumbe University

Resources available: SSM, FoUS members, and Mzumbe University

Constraints: time, political environment, level of education of FoUS members.

Problem owners: FoUS and District Council (district office as well as villages with attractions).

Implications on problem owner: FoUS did not know the value of collecting basic data on tourists and how the information can be used to improve business

Value to problem owner: Solving the problem would increase ability to conduct customer relationship management $(\mathrm{CRM})$ and promote Lushoto tourism products using customers visiting Lushoto. Also, it would lead to improvement of the effectiveness of the Society in providing information needed by several stakeholders as well serve tourists better, which was the ultimate goal. 


\section{Analysis Two: Roles, Norms and Values}

Analysis Two required members to discuss and summarise what were the roles, norms and values of FoUS. The output of discussion is summarised below.

\section{Roles:}

FoUS roles included the relations between members (tour guides, various committees, and principals), district council, villages where tourist attractions were located. Specifically, the roles of FoUS were considered to be:

- Tourist information gatherer and provider

- Provider of guiding services

- Effective management of collected financial resources from different sources (for example tour guiding fees as well membership fees).

- Member of Tanzania Cultural Tourism Organisation (TACTO)

\section{Norms:}

Participants felt that FoUS norms included fulfilling Society's objective effectively.

\section{Values:}

Participants delineated five values which are summarized below:

- Commitment to provide high quality services to tourists

- Commitment of conserving the Usambara Mountains environment

- Commitment to the development of sustainable tourism

- Commitment to share benefits to villages through VDF

- Commitment of using resources efficiently.

\section{Analysis Three: Political Analysis}

Political analysis was meant to stimulate participants to think about power issues which were considered vital to understand as they affected FoUS wellbeing. Two issues were identified as part of nature of power as follows: Willingness to increase transparency in distribution of financial resources collected on behalf of villages where tourist attractions were located. This implied providing access to information to village leaders and ability to persuade the villagers to see themselves as beneficiaries of local tourism system (FoUS claimed to collect VDF and distribute to village projects, however, some villages were not happy and had planned to erect barrier to collect own fee from tourists). Secondly, district authority did not recognise tourism as an important activity in the district thus provided little support to FoUS. Therefore more ability to influence the district authorities to act as a proper local destination management organisation was underscored.

\section{Rich Picture}

The results of the rich picture analysis are shown in Figure 2. As seen from the picture drawn, one can understand the problem situation in more concrete way. 
Figure 2: Rich Picture of Lushoto Rural Tourism System

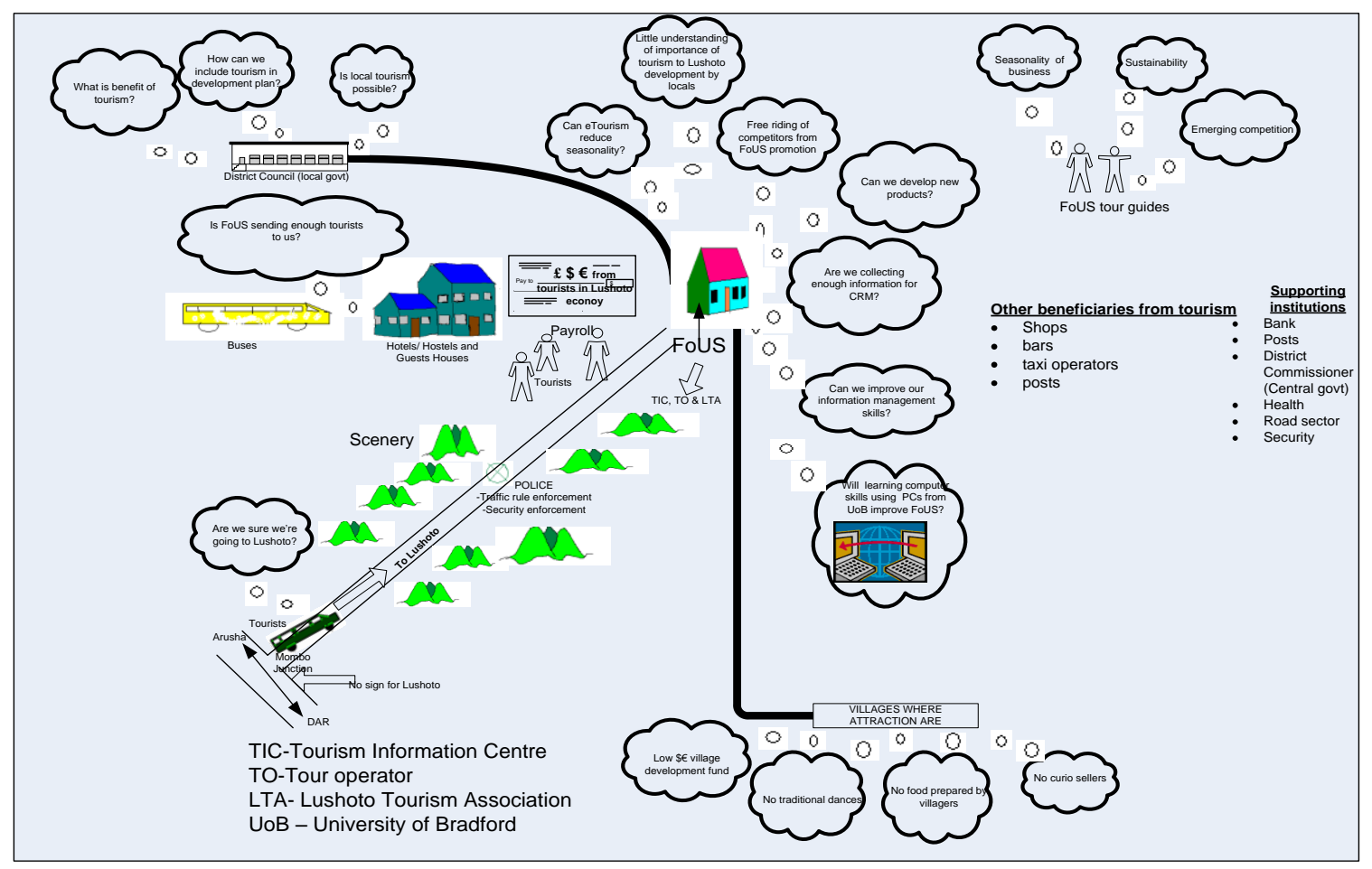

Some of salient features from the Rich Picture show that FoUS receives tourists in office and provides both information on availability of services (accommodation, hotels and attractions) and guiding services at a fee. The aim of this study, as stated before, was to try to help FoUS manage tourist information for effective customer relationship management (CRM) and enhance their contribution economic and social contribution to the Lushoto district society. The diagram also lists several concerns of FoUS members on possible ways of improving services offered to their customers. The concerns included the quest of learning skills to manage TIS as well raising their IT skills (using PCs donated by University of Bradford). Other concerns related to effect of tourism seasonality on tour guides livelihoods, lack of effective leadership from the district council, and the issues of sustainability of the tourist products in the destination.

\section{Naming of Relevant Systems}

In this phase attempts were made to name relevant systems as explained before. Result of the root definition for the system of FoUS is summarised as "Improved tourist information management for increasing customer satisfaction and attract more visitors and justify our role to the Lushoto District Council leadership so that they should support our efforts of promoting 
sustainable tourism." In addition, at this stage another CATWOE analysis for this relevant system was conducted with the following result:

$\mathrm{C}=$ Tourists and local community

$\mathrm{A}=$ Tour Guides and FoUS in general

$\mathrm{T}=$ Books, pamphlets, people (tourists, and local)

$\mathrm{W}=$ People, visibility, accurate information, relationship/collaboration

$\mathrm{O}=$ FoUS

$\mathrm{E}=$ Roads, Institutions (church, mosques, police stations, executive committee of FoUS (which sets society policy) and District Council (for overall operating policy and good governance)

The conceptual model for this system was developed using the minimum number of activities to carry out this relevant system as summarised in the following human activity systems.

\section{Human Activity Systems}

To address the above problem as identified and agreed during the focus discussion group sessions, the following human activity systems were suggested:

i. Appreciate the importance of information and effective communication in tourism business (since tourism is information business)

ii. Plan to improve management of information provided by customers (tourists) from collection to analysis

iii. Appreciate the importance of after sale communication with customers, that is, to tourists after visiting Lushoto

iv. Plan for more advertisement of FoUS (sign board as well websites)

v. Plan to improve the guest book to include the e-mail and customer's sex columns

vi. Plan to learn information technology skills using PCs loaned from University of Bradford.

vii. Survey by means of questionnaire on the sources of information on Lushoto for international tourists

viii. Activities to prepare receiving PCs: Plan to wire the provided room, sign an agreement with Mzumbe University (MU), and give the DED a copy.

ix. Plan to attend the course (a careful selection of would be trainees after attaining some training criteria)

x. Undertake training needs analysis

xi. Use the learned skills to raise efficiency of FoUS 
xii. Strive to influence the political climate in Lushoto so that DED can appreciate better the role of tourism in the district

xiii. Monitor activities

xiv. Evaluate the impact of intervention

On top of drawing the above Rich Picture, the members of the group drew the stakeholders diagram as presented in Figure 3. The purpose was to ensure that the participants appreciated the interconnection of various players in the chain. The chain metaphor was strengthened by a discussion on an adage which says "the chain was strong as its weakest point." Figure 3 demonstrates how several institutions are part of the Lushoto tourism value chain.

Figure 3: Stakeholders in Lushoto Rural Tourism

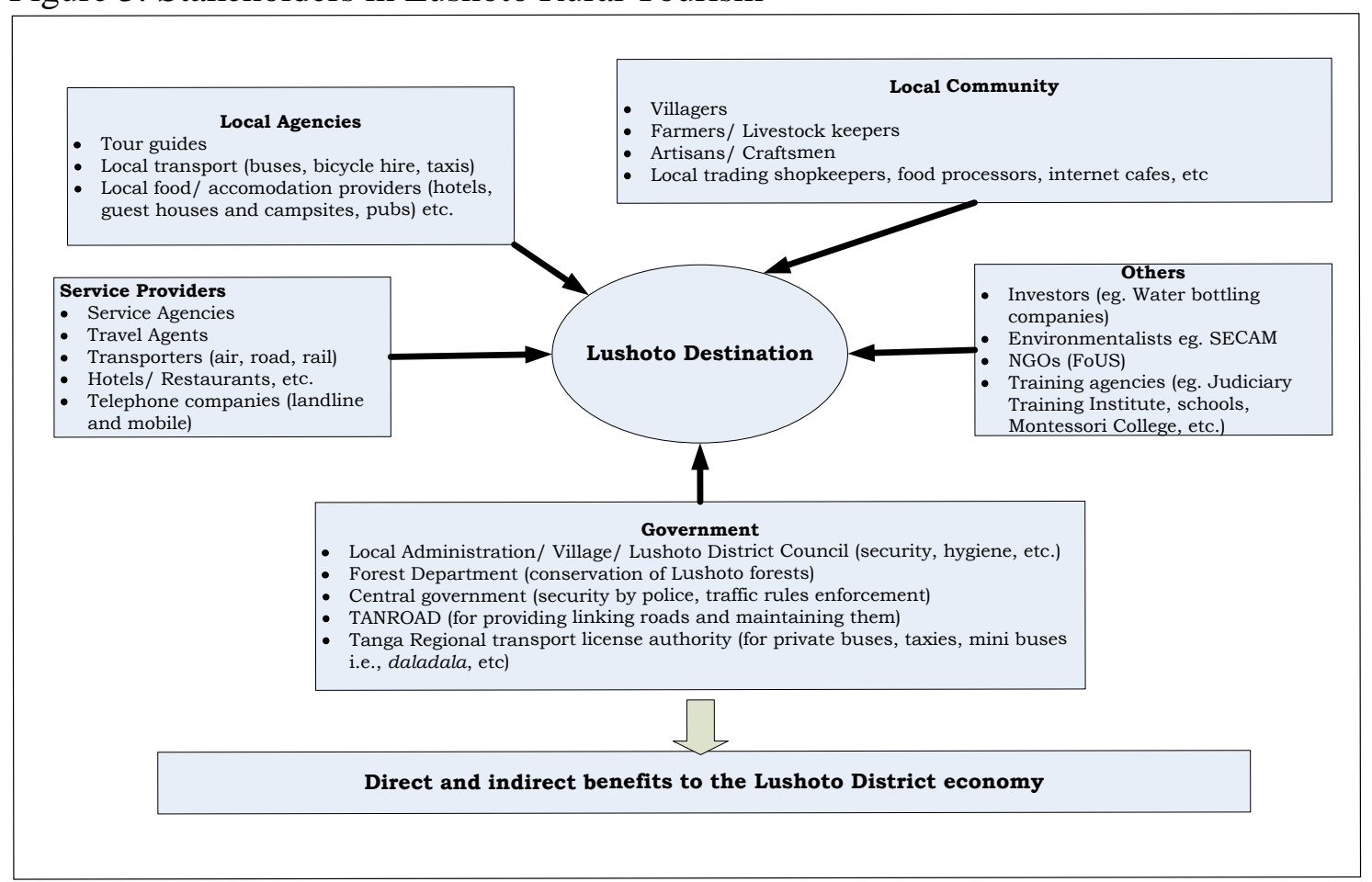

Source: Lushoto Focus Discussion Group

The stakeholders were broadly divided in five categories, namely, government, service providers, local community, local agencies, and others. Institutions under the government categories included the central government which was responsible for security and traffic laws enforcement. Other institutions under government were the regional government as well as Lushoto district council. The council was responsible for enforcement hygiene issues.

\section{Implementation of Activities after SSM Workshop}

As the fifth stage of SSM version 3 (taking action), immediately after the seminar members of the society started to prepare the room they had designated to host the personal computers donated by University of Bradford through Mzumbe University. When the room was ready in 
terms of furniture and electrical wiring, the PCs were delivered. Members participated actively in putting together various components of PCs.

\section{Basic Computer and Web Authoring Training}

The training was done by the author in collaboration with an expert from the Tanzania Commission of Science and Technology (COSTECH). However, before starting the training, the researcher had carried a training needs assessment (TNA) to determine the level of computer skills of each trainee. All members had indicated that they had low skill levels in computer use. In terms of education level, all had completed Ordinary Level (General Certificate of Second Education) but had not passed well in their examinations to be able to pursue further studies. Before undertaking the training, each trainee was invited officially by the Executive Secretary of the Society and required to assent that he/she would be available all the time of training. However, despite the fact that members signed an agreement that they would be present all time of training, realities of adult education forced some trainees to leave the sessions early or report late. Since training was taking place in the society's office, any time a tourist would arrive, some one would leave the training room to attend the visitor. If the visitor required a guiding service, one or two tour guides (trainees) would be away for a day or two. At the end of the training, even though everyone rated the training as excellent, not much had been learned by majority of the participants. A plan of designing a Society's website with the trainees did not materialize, since due to the above interruptions, low level of computer skills, and low level of understanding the technical language of computer application as well as web design resulted into the slow acquisition of the intended skills.

After the end of the planned training programme, it was agreed among the trainers (expert from COSTECH and the author) that we give more time for the trainees to continue working on the website construction. After the training, the author travelled to Lushoto four times and met members of the society who were developing the website and assisted them. Even though the website was not "formerly" completed, off-shoots of the design were uploaded on one of the free hosting services as well as creation of http://friends-of-usambaramtn.blogspot.com/ blog.

Another strategy that was pursued was to try to convince the Lushoto district executive director (DED) to fund the construction of Lushoto District Council website as one of the means of implementing electronic governance which had been promulgated by the central government. One of the services that was planned to be promoted by the website would have been rural tourism. The DED requested the author to prepare a proposal. The proposal was prepared in collaboration with Economic and Social Research Foundation (ESRF). However, the proposal was not implemented.

\section{Redesigning the Guest Book}

Since tourism is basically information-based business, the trainees realised after the experiential training (participants contributed fully their experiences) that the Society had not been serious in collecting relevant information from the customers. In addition, when members evaluated the instrument of data collection (guest book), it was realised that the instrument itself was quite deficient since some of the data it was supposed to collect could not be used by the Society in its customer relationship management (CRM) endeavours. It was thus decided to modify some of the fields in the book so that the relevant data should be collected from the customers. After the 
above agreement, the Friends of Usambara Society funded the printing of the guest book with the relevant fields. This was another action-taking activity as per SSM step 5. Utilisation of the book was emphasized and the tour guides became keen on making sure all willing tourists were writing up their particulars in the book. An evaluation of the use of the Guest Book before and after the training shows that the Society collected sufficient information from the majority of the visitors after the training. Therefore, if the society wants to make use of these customers (for example in further marketing activities), it is within their capacity to do so. Otherwise, the first guest book which was purchased off-shelf had a few fields and some of them were completely useless. The old guest books had four fields, namely, Date, Name of Visitor, Address, and Signature fields (see Figure 4).

Figure 4: Old guest book fields

\begin{tabular}{|c|c|c|c|}
\hline Date & Name & Address & Signature \\
\hline & & & \\
\hline
\end{tabular}

The new guest book included Sex, E-mail address, Occupation and Telephone (option) fields in addition of common fields of Date, Name and Address fields (see Figure 5).

Figure 5: New guest book fields

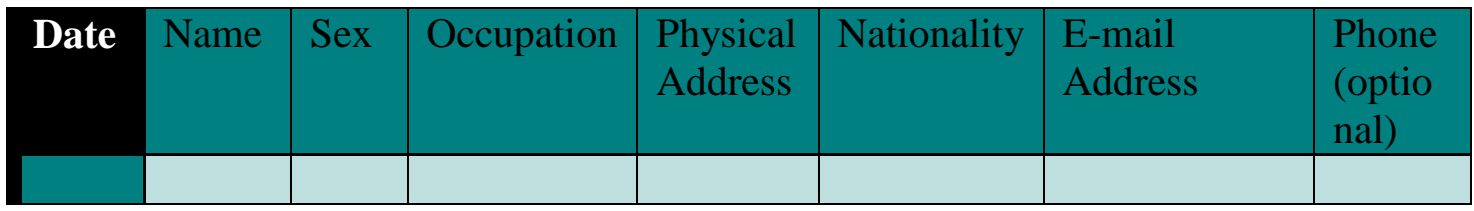

Compared to other means of communication, e-mails are more cost effective and efficient in term of time and costs, as described earlier, hence its inclusion in the new book. In addition, the old book did not have a column for visitor's sex and nationality. Thus, formerly, only a partial picture of the visitors could be obtained

\section{Summary and Conclusion}

The paper has presented results from a case study that employed SSM as one of the Soft OR methods. The case study used action research which involved training in information technology skills of Friends of Usambara Society members. A lot of learning was garnered. Despite the fact that some of the training objectives, especially, the commercial website creation for FoUS were not fully realised, some digital offshoots such as updated blog by the Society was developed. In addition, several activities which could enhance tourism activities in Lushoto were implemented. These included designing the appropriate Guest Book for the modern world which can be used to collect visitors' information for customer relationship management.

Engaging relevant stakeholders in Lushoto to construct both the Rich Pictures and Stakeholders Diagrams enabled the participants to understand the connectedness of many players in running rural tourism. This was considered important since the respondents resolve of cooperating with 
other partners was raised after the realisation of the connectedness. Also, after the training members of the Society appreciated the importance of managing tourism information and empowering nature of the web whereby as a Society they could easily (cost and timeliness wise) update information designed to potential tourists.

It can therefore be concluded that in fuzzy and complex situations such as those involved in rural development, Soft OR methods are more appropriate. This is because societal problems are usually complex and adaptive.

\section{References}

Baskerville, R., \& Wood-Harper, A. T. (1998). Diversity in information systems action research methods. European Journal of Information Systems, 7(2), 90-107.

Buhalis, D. (2003). eTourism: Information Technology for Strategic Tourism Management. London: Financial Times/Pearson Education.

Butler, R. (1980). The Concept of a Tourist Area Cycle of Evolution: Implications for Management of Resources. Canadian Geographer, 24, 5-12.

Carlsen, J. (1999). A systems approach to island tourism destination management. Systems Research and Behavioral Science, 16(4), 321-327.

Checkland, P. B. (1990). Systems Thinking, Systems Practice. New York: John Wiley \& Sons.

Checkland, P. B., \& Holwell, S. (1998). Information, Systems and Information Systems. Chichester.: Wiley.

Guba, E., \& Lincoln, Y. S. (1994). Competing paradigm in qualitative research. In N. K. Denzin \& Y. S. Lincoln (Eds.), Handbook of Qualitative Research. Thousand Oaks, CA.: Sage.

Gurstein, M. (2001). ,Community informatics, community networks and strategies for flexible networking. In L. Keeble \& B. Loader (Eds.), Community informatics: Shaping computer-mediated social relations (pp. 263-283). London: Routledge.

Heyer, R. (2004). Understanding Soft Operations Research: The methods, their application and its future in the Defence setting. DSTO Information Sciences Laboratory.

Hult, M., \& Lennung, S.-A. (1980). Towards a Definition of Action Research: A Note and Bibliography. Journal of Management Studies(May), 241-250.

Monk, A., \& Howard, S. (1998). The Rich Picture: A Tool for Reasoning about Work Context. Interactions(March-April), 21-30.

Mwenguo, P. (2003). Tanzania Tourism Board Director (pp. Personal Communication).

Russell, R., \& Faulkner, B. (2004). Entrepreneurship, chaos and the tourism area lifecycle. Annals of Tourism Research, 31(3), 556-579.

Stamboulis, Y., \& Skayannis, P. (2003). Innovation strategies and technology for experiencebased tourism. Tourism Management, 24(1), 35-43.

Various. (2009). Letters to Editor: The Case for Soft O.R. [Electronic Version]. Retrieved June 1, 2009, from http://lionhrtpub.com/orms/orms-4-09/letters.html 